\title{
THE INTENSITY OF CHRONIC CATARRHAL GINGIVITIS IN CHILDREN DEPENDING ON THE AGE
}

D0I: 10.36740/WLek202005102

\author{
Petro A. Hasiuk', Nataliia V. Malko², Anna B. Vorobets', Viktoriya V. Ivanchyshyn², Svitlana 0. Rosolovska², \\ Mariia M. Korniienko' ${ }^{2}$, Oleksandr A. Bedenyuk' ${ }^{1}$ \\ II. HORBACHEVSKY TERNOPIL NATIONAL MEDICAL UNIVERSITY, TERNOPIL, UKRAINE \\ 2DANYLO HALYTSKY LVIV NATIONAL MEDICAL UNIVERSITY, LVIV, UKRAINE
}

\begin{abstract}
The aim: To determine the degree of severity of the inflammatory process in periodontal tissues of children living in different ecological conditions.

Materials and methods: With the purpose of estimation of the condition of periodontal tissues the epidemiology examination of 642 children that live on territory with the high level of pollution and natural deficit of iodine and fluorine was conducted.

Results: The study found that the increase of age of examined children causes the decrease of percentage of easy degree of severity of chronic catarrhal gingivitis, giving way to the advanced forms of the disease, and this process was more pronounced in children living in ecologically polluted region. In children-inhabitants of ecologically clean region easy degree of severity of chronic catarrhal gingivitis met more often than their peers living in environmentally polluted region. At the same time, average and heavy degree of severity of chronic catarrhal gingivitis in children living in ecologically contaminated region met more often than their peers, inhabitants of ecologically clean region. Conclusions. It was found that with increasing age of the examined children decreases the percentage of chronic catarrhal gingivitis of moderate severity.
\end{abstract}

KEY WORDS: children, ecology, periodontal diseases, gingivitis, periodontal tissues

Wiad Lek. 2020;73(5):846-849

\section{INTRODUCTION}

The recent year's studies indicate a high prevalence of the main dental diseases in children living in ecologically unfavorable regions. Periodontal diseases take the second place on the frequency and prevalence after caries, what is significant problem of pediatric dentistry $[1,2,3,4]$.

There is formed powerful industrially-agrarian complex in Lviv region, which is also one of the factors of destabilization of ecological situation and related to the functioning of large enterprises in the mining, chemical and energy industries $[2,5]$.

The territory of Lviv region is characterized by peculiar geochemical conditions with significant deficit of essential trace elements in the soils such as zinc, copper, iodine, fluoride in drinking water and significant environmental pollution $[6,7]$. The indicators of general and dental health of children are significantly worse in such conditions $[8,9]$.

The children are especially sensitive to the effects of negative environmental factors, that caused by age immaturity of protective and adaptive mechanisms, and the state of health of the younger generation can be considered as the main indicator of the state of environment $[10,11,12]$.

The pediatric dentistry till has the problem of timely diagnostics and treatment of periodontal disease in children, living in ecologically unfavorable regions despite the achieved successes in pediatric periodontics $[13,14]$.

Given the preventive direction of children's dental care, it is important to identify the factors influencing the formation of pathology, establishing the clinical features of diseases and their mechanisms of appearance, development of directed as pathogenic treatment and preventive events that will help to prevent the development of severe forms of lesions of the periodontal tissues.

\section{THE AIM}

The aim of the research was to determine the degree of severity of the inflammatory process in periodontal tissues of children living in different ecological conditions.

\section{MATERIALS AND METHODS}

This study was approved by the ethics committee of the Danylo Halytsky Lviv National Medical University, Lviv, Ukraine. All procedures were carried out in accordance with the ethical standards of the responsible committee on human experimentation and with the Helsinki Declaration of 1975 , as revised in 2000.

With the purpose of estimation of the condition of periodontal tissues the epidemiology examination of 642 children that live on territory with the high level of pollution and natural deficit of iodine and fluorine (cities Yavoriv and Zhydachiv) was conducted. For the control data 214 children-inhabitants of Lviv that characterized as condi- 

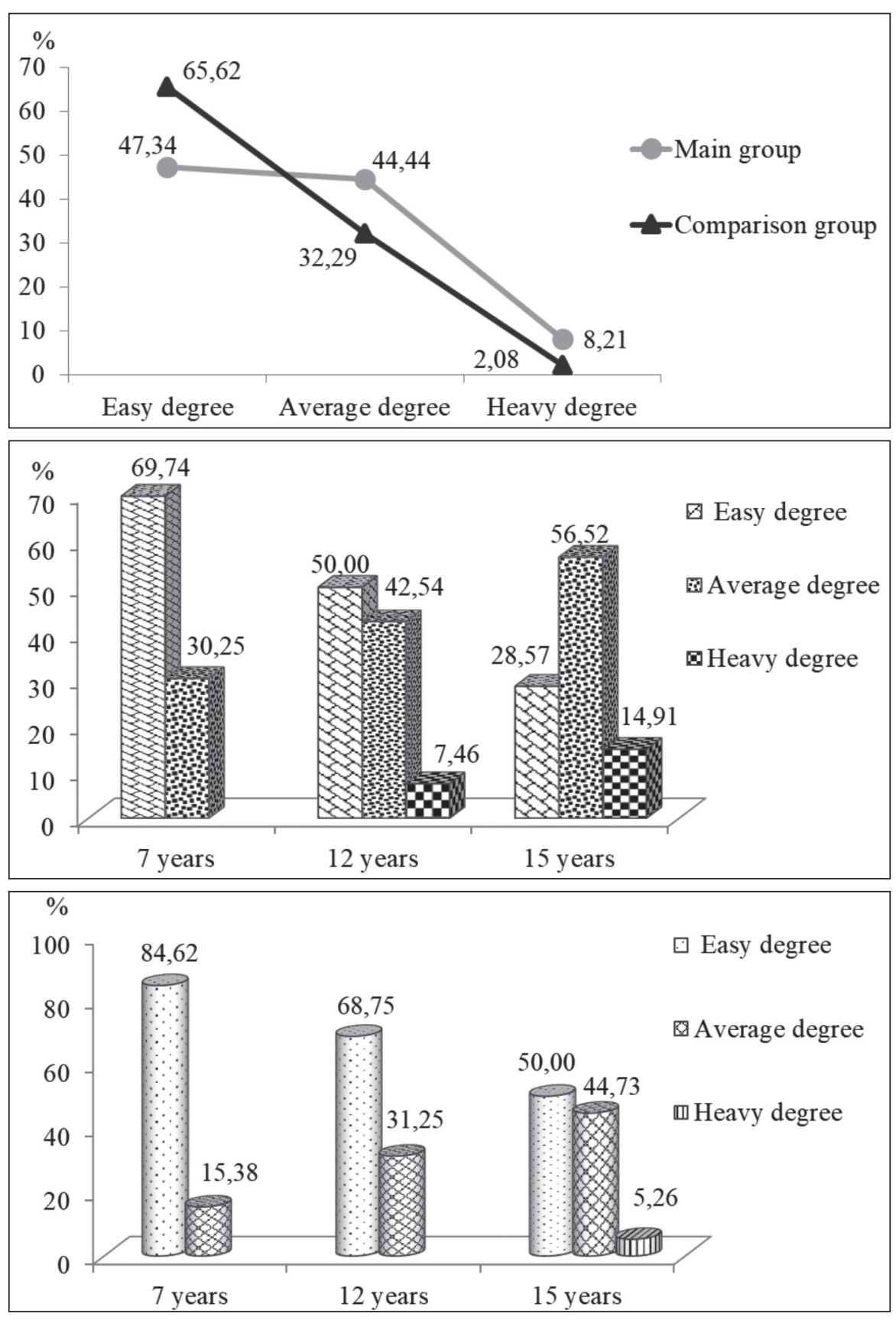

Fig. 1. - Degrees of severity of chronic catarrhal gingivitis in children of study groups.

Fig. 2. - Degrees of severity of chronic catarrhal gingivitis in children of main group depending on age.

Fig. 3. - Degrees of severity of chronic catarrhal gingivitis in children of comparison group depending on age. tionally „clean region” were examined. Children of the 7 , 12 and 15 years-old according to the recommendations of the World Health Organization were examined. The state of periodontal tissues was estimated on the results of questioning, review of oral cavity and use of periodontal indexes and tests (index of PMA, index of bleeding, test of Shiller-Pysaryev). The obtained data were worked out statistically using licensed programs „Microsoft Excel” and "Statistica 5.5”.

\section{RESULTS}

On the Figure 1 is shown that in children living in ecologically polluted region easy degree of severity of chronic catarrhal gingivitis was on average $(47.34 \pm 3.57) \%$ of exam- ined, whereas in children from ecologically clean region its mean was higher and equaled to $(65.62 \pm 5.98) \%(\mathrm{p}<0.05)$.

In children of main group the proportion of average degree of severity of chronic catarrhal gingivitis was $(44.44 \pm 3.55) \%$, which exceeded the values in comparison group, where the same degree of gingivitis was diagnosed in (32.29 \pm 8.39$) \%$ of examined ( $p>0.05)$. The heavy degree of severity of chronic catarrhal gingivitis in children from EPR met more often than their peers from ECR - $(8.21 \pm 1.96) \%$ against $(2.08 \pm 0.69) \%$ respectively $(\mathrm{p}<0.05)$.

The analysis of prevalence of chronic catarrhal gingivitis (CCG), depending on children's age showed that in inhabitants of polluted region at the age of 7 years easy degree of CCG met in $(69.75 \pm 4.21) \%$ of examined ( $p>0.05)$, average degree of CCG was in $(30.25 \pm 4.21) \%$ of children 
$(\mathrm{p}>0.05)$. The heavy degree of CCG was not diagnosed in 7-years-old children (Fig. 2).

In 12-years-old children of main group the proportion of easy degree of CCG decreased to $(50.00 \pm 4.32) \%(\mathrm{p}<0.05)$. At the same time in children of the same age group from EPR average degree of severity was in $(42.54 \pm 4.27) \%$ of examined ( $p>0.05)$. At the age of 12 -years in 10 examined children $(7.46 \pm 2.26) \%$, what has felt the influence of anthropogenic load met $\mathrm{CCH}$ of heavy degree of severity.

In 15-years-old children from EPR observed further reduction of amount of examined with easy degree of CCG a percentage of which was $(28.57 \pm 3.56) \%(\mathrm{p}<0.05)$. At the same time, in 15-years-old children of this group had increased the amount of examined with average degree of CCG - (56.52 \pm 3.91$) \%(\mathrm{p}>.05)$, which was higher relatively to the data obtained from 7-12-years-old children of main group with CCG of average degree of severity. Heavy degree of CCG diagnosed in 24 examined $(14.91 \pm 2.81) \%$ at the age of 15 years of main group $(p<0.05)$.

At the same time, most 7-years-old children living in ecologically clean region was found easy degree of CCG $(84.62 \pm 7.07) \%$, while average degree of CCG diagnosed in 2 times less (15.38 \pm 7.07$) \%$ compared to the corresponding values in children from EPR. The heavy degree of CCG was not diagnosed in 7-years-old children of comparison group (Fig. 3).

At the age of 12 years in children-inhabitants of EPR observed similar tendency decreasing of prevalence of easy degree of CCG to $(68.75 \pm 8.19) \%$ while increasing the proportion of average degree of CCG to $(31.25 \pm 8.19) \%$. In children from EPR in this age interval was not diagnosed heavy degree of CCG.

In 15-years-old inhabitants of ecologically clean region noted the decrease of amount of examined with CCG to $(50.00 \pm 8.11) \%$ at the increase of amount of children with average degree of CCG to $(44.74 \pm 8.06) \%$. Heavy degree of CCG in this age group found in $(5.26 \pm 3.62) \%$ of examined children from EPR.

\section{DISCUSSION}

Many researchers have established the high prevalence of major dental diseases in children living in ecologically disadvantaged regions. Children are especially sensitive to the effects of negative environmental factors, which is explained by the age immaturity of the protective and adaptive mechanisms of their organism $[13,14]$.

Analyzing the results of a study of the prevalence of chronic catarrhal gingivitis, it was found that in children living in ecologically polluted territories a mild degree of gingivitis occurs in $69.75 \%$. Gingivitis of moderate severity was found in $30.25 \%$. A severe degree of chronic catarrhal gingivitis was diagnosed in $14.91 \%$ of the examined children 15 years old. Children living in ecologically clean regions have significantly lower rates of this disease.

The results of our clinical studies showed a significant influence of the environmental pollution and geochemical features of the territory on the condition of periodontium.
In children from ecologically polluted regions these processes were more pronounced, which was associated with the intensification of inflammatory processes in the children's periodontium as well as the prolonged action of the combined negative environmental factors.

\section{CONCLUSIONS}

Thus, with increasing age of examined children decreased percentage of chronic catarrhal gingivitis of easy degree of severity, giving way to the advanced forms of the disease, and this process was more pronounced in children living in ecologically polluted region.

\section{REFERENCES}

1. Bezvushko E.V., Klymchuk M.A. Vplyv zabrudnennya navkolyshn'oho seredovyshcha na zakhvoryuvannya zubiv u ditey [The influence of environmental pollution on dental morbidity of children]. Environment and health. 2006;2:65-8. (UA).

2. Bezvushko E.V. Osoblyvosti formuvannya patolohiyi parodonta u ditey, shcho prozhyvayut' v riznykh ekolohichnykh umovakh [Features of formation of periodontal pathology in children, living in different ecological conditions]. Visnyk stomatologiyi. 2008;2:97-101. (UA).

3. Leshchuk Ye.S., Ivanchyshyn V.V., Hasiuk P.A., et al. Analysis of the oral fluid's $\mathrm{pH}$ depending on the state of fissures of the first permanent molars in children. World of Medicine and Biology. 2018;3:68-70.

4. Zubchenko S.G., Malko N.V., Hasiuk P.A., et al. Corellation between immunological indexes of the oral liquid in children with chronic catarrhal gingivitis. World of Medicine and Biology. 2019;3(69):108-12.

5. Godovanets O.I., Rozhko M.M., Popovych Z.B. Osoblyvosti klinichnoho perebihu khronichnoho kataral'noho hinhivitu u ditey, yaki prozhyvayut' na terytoriyi iz pidvyshchenym rivnem nitrativ u pytniy vodi [Features of the clinical course of chronic catarrhal gingivitis in children, living on the territory with increased level of nitrates in drinking water]. Galician medical bulletin. 2007;3:15-7. (UA).

6. Luchynskyi M.A., Lychunska Yu.I., Ostapko 0.I. Vplyv nehatyvnykh faktoriv navkolyshn'oho seredovyshcha na riven' zakhvoryuvanostizubiv $u$ dytyachoho naselennya [The influence of negative environmental factors on the level of dental morbidity of the child population]. Bulletin of problems of biology and medicine. 2015;2(1):221-3. (UA).

7. Modina T.N., Mamayeva E.V., Lopatkina 0.N. Patolohiya tkanyn parodonta ta funktsional'noho stanu orhanizmu pidlitkiv [Pathology of periodontal tissues and the functional state of organism of adolescents]. Pediatric dentistry and prevention. 2006;1-2:78-84. (UA).

8. Morón E.M., Tomar S.L., Souza R., et al. Dental Status and Treatment Needs of Children in Foster Care. Pediatr Dent. 2019;41(3):206-210.

9. Nicolau B., Castonguay G., Madathil S., et al. Periodontal Diseases and Traumatic Dental Injuries in the Pediatric Population. Pediatr Clin North Am. 2018;65(5):1051-61.

10. Saheer P.A., Parmar P., Majid S.A., et al. Effect of sugar-free chewing gum on plaque and gingivitis among 14-15-year-old school children: A randomized controlled trial. Indian J Dent Res. 2019;30(1):61-66.

11. Stephens M.B., Wiedemer J.P., Kushner G.M. Dental Problems in Primary Care. Am Fam Physician. 2018;98(11):654-660.

12. Togoo R.A., Al-Almai B., Al-Hamdi F., et al. Knowledge of Pregnant Women about Pregnancy Gingivitis and Children Oral Health. Eur J Dent. 2019;13(2):261-270.

13. Mombelli A., Walter C. Antibiotics in Periodontics. Swiss Dent J. 2019;129(10):835-838. 
14. Petrini M., Costacurta M., Biferi V., et al. Correlation between halitosis, oral health status and salivary ß-galactosidases and time spent in physical activities in children. Eur J Paediatr Dent. 2018;19(4):260-64.

The work is a fragment of the research project of the orthopedic dentistry department I. Horbachevsky Ternopil National Medical University "Multidisciplinary approach to the study of the pathogenesis and treatment of main dental diseases based on the study of mechanisms of damage to the tissues of the oral cavity against the background of concomitant somatic pathology» (State Registration No. 0119U002431).

\section{ORCID and contributionship:}

Petro A. Hasiuk - 0000-0002-2915-0526 ${ }^{A}$

Nataliia V. Malko - 0000-0002-3272-1836 ${ }^{\mathrm{C}}$

Anna B. Vorobets - 0000-0002-4119-7896 ${ }^{B}$

Viktoriya V. Ivanchyshyn - 0000-0002-7523-144X ${ }^{D}$

Svitlana O. Rosolovska - 0000-0003-4768-3905 ${ }^{\mathrm{E}}$

Mariia M. Korniienko - 0000-0002-4345-6775 D

Oleksandr A. Bedenyuk - 0000-0002-9644-1809 ${ }^{F}$

\section{Conflict of interest:}

The Authors declare no conflict of interest.

\section{CORRESPONDING AUTHOR}

Anna B. Vorobets

m.Voli St., 1, 46001, Ternopil, Ukraine

tel: +380968783459

e-mail: vorobecab@tdmu.edu.ua

Received: 20.01.2020

Accepted: 01.04 .2020

A - Work concept and design, B - Data collection and analysis, C - Responsibility for statistical analysis,

D-Writing the article, $\mathbf{E}$-Critical review, $\mathbf{F}$ - Final approval of the article 